\title{
Lipid and fatty acid composition of parasitic caligid copepods belonging to
} the genus Lepeophtheirus

\author{
J. A. Tocher, J. R. Dick, J. E. Bron, A. P. Shinn and D. R. Tocher*
}

Institute of Aquaculture, University of Stirling, Stirling FK9 4LA, Scotland, United Kingdom

Running title: Lipid composition of Lepeophtheirus salmonis

Key words: Lepeophtheirus salmonis, salmon lice, lipid, fatty acid, copepod

* To whom correspondence should be addressed

Douglas Tocher

Institute of Aquaculture, University of Stirling, Stirling FK9 4LA, Scotland, UK. Phone: +441786 467996; Fax: +44 1786 472133; E-mail: d.r.tocher@stir.ac.uk

\section{Abstract}

Sea lice are copepod ectoparasites that constitute a major barrier to the sustainability and economic viability of marine finfish aquaculture operations worldwide. In particular, the salmon louse, Lepeophtheirus salmonis, poses a considerable problem for salmoniculture in the northern hemisphere. The free-swimming nauplii and infective copepodids of L. salmonis are lecithotrophic, subsisting principally on maternally-derived lipid reserves. However, the lipids and fatty acids of sea lice have been sparsely studied and therefore the present project aimed to investigate the lipid and fatty acid composition of sea lice of the genus Lepeophtheirus obtained from a variety of fish hosts. Total lipid was extracted from eggs and adult female Lepeophtheirus salmonis obtained from both wild and farmed Atlantic salmon (Salmo salar L.) sampled at two time points, in the mid 1990's and in 2009. In addition, L. salmonis from wild sea trout (Salmo trutta L.) and L. hippoglossi from wild Atlantic halibut (Hippoglossus hippoglossus L.) were sampled and analyzed. The lipids of both females and egg strings of Lepeophtheirus were characterized by triacylglycerol (TAG) as the major neutral (storage) lipid with phosphatidylcholine and phosphatidylethanolamine as the major polar (membrane) lipids. The major fatty acids were 22:6n-3 (DHA), 18:1n-9 and 16:0, with lesser amounts of 20:5n-3, 22:5n-3 and 18:0. L. salmonis sourced from farmed salmon were 
characterized by higher levels of 18:2n-6 and 18:3n-3 than lice from wild salmon. Egg strings had higher levels of TAG and lower DHA compared to females, whereas L. hippoglossi had lower levels of TAG and higher DHA than L. salmonis. The results demonstrate that the fatty acid compositions of lice obtained from wild and farmed salmon differ and that changes to the lipid and fatty acid composition of feeds for farmed salmon influence the louse compositions.

\section{Introduction}

Copepods are a group of small crustaceans found in most marine and freshwater habitats of the world. More than 14,000 species have thus far been described, with sizes typically being in the range of $<1$ to $6 \mathrm{~mm}$. Many copepods are herbivorous, often feeding on phytoplankton, whilst others may be detritivores, predators or commensals, some of which are fully parasitic. Copepods are considered to be the most numerous metazoans on the planet, exceeding the numbers of the other two hyperabundant groups: insects and nematodes. As such, they are generally assumed to constitute the predominant biomass of zooplankton and are the major food for many fish, larger crustaceans, sea mammals and seabirds (Skjoldal et al., 2004). Many copepods, particularly those in cold or deep waters, build up large lipid energy reserves through feeding on phytoplankton. These lipids are stored in oils sacs and / or as oil droplets. In some species lipid may accumulate to between 50-70 \% of body dry weight (Kattner and Krause, 1989; Lee et al., 2006; Falk-Petersen et al., 2009), making copepods the principal source of dietary lipid for many plankton-feeding fish species.

Parasitic copepods of the genus Lepeophtheirus constitute one of the most serious pathogens of marine farmed salmonids the world (Johnson et al., 2004). It is estimated that sea lice infection by species belonging to the genera Lepeophtheirus and Caligus, cost the world's eight major salmon-producing countries, a combined total of over $€ 300$ million (Costello, 2009). Sea lice can pose a considerable risk to fish health and can inhibit growth, cause external damage and, in extreme cases, lead to mortality (Pike and Wadsworth, 1999). Sea lice are therefore a major constraint to farm production in coldwater salmoniculture and have also been suggested to be a threat to wild salmonid populations such as sea trout (Ford and Myers, 2008).

The species of copepod parasite of prime concern to mariculture and wild fisheries in Scotland is the salmon louse, Lepeophtheirus salmonis, which is the most pathogenic marine ectoparasite of Atlantic salmon (Salmo salar L.). The life cycle of this species is well characterized, comprising 10 stages separated by moults and five developmental phases (Kabata, 1979). After hatching from paired egg strings carried by host-attached adult females, the lice progress through two free-swimming planktonic nauplius stages before developing into copepodids, which infect a 
new fish host (Schram, 1993). After attachment, development proceeds through four chalimus and two sexually differentiated preadult stages before sexual maturity is reached at the adult stage. During development on the fish host, lice survive by feeding exclusively on host material including mucus, skin and blood (Brandal et al., 1976; Jonsdottir et al., 1992). Off the host, free-living stages of L. salmonis, nauplii and copepodids, are sustained by body reserves until the infective copepodid larva attaches to a new host (Boxaspen, 2006).

Despite considerable research into the biology, genetics and control of sea lice (Pike and Wadsworth, 1999; Boxaspen, 2006), very little is known about lipids and lipid metabolism in $L$. salmonis and in parasitic copepods in general. The period of survival of the free-swimming copepodid stage is constrained by its endogenous energy supplies (Boxaspen, 2006). The available energy reserves of $L$. salmonis copepodids were estimated at $7800 \mathrm{cal} \mathrm{g}^{-1}$ dry weight by bomb calorimetry, this being similar to reserves reported for copepodid stages of other parasitic and freeliving copepods during winter (Tucker et al., 2000). This figure declined sharply between 1-2-dayold and 7-day-old copepodids with those at 7 days having substantially depleted reserves. In addition to their role as energy reserves, lipids are also key to the parasite's ability to immunomodulate the host. In this respect, L. salmonis has been demonstrated to secrete prostaglandin $\mathrm{E}_{2}$, an arachidonic acid (ARA; 20:4n-6) metabolite (Fast et al., 2004).

In contrast to the parasitic copepods, there has been considerable research into lipid storage and lipid metabolism in free-living copepods (see Lee et al., 2006; Kattner et al., 2007). An initial comparison of lipids in free-living and parasitic species (Lee, 1975) reported that, unlike the lipids of many free-living marine copepods that use wax esters (WE) as their primary energy store, $L$. salmonis from Pacific coho (Oncorhynchus kisutch) and pink (O. gorbuscha) salmon and other parasitic caligid copepods used triacylglycerol (TAG) as their main energy store. This was confirmed for L. salmonis from Atlantic salmon by Tucker et al. (2000). Given the paucity of information concerning lipids in caligid copepods, the present study therefore investigated lipid class and fatty acid compositions of total lipids of sea lice of the genus Lepeophtheirus obtained from a variety of fish hosts.

\section{Materials and Methods}

\subsection{Samples and sampling}

Individual lice of the genus Lepeophtheirus were collected from infected fish obtained from various sites in Scottish waters (Table 1). Collected sea lice were maintained in fresh seawater (minimum $33 \mathrm{ppt}$ ) at $10{ }^{\circ} \mathrm{C}$ with aeration for approximately $24 \mathrm{~h}$ prior to processing. This study used samples of L. salmonis, collected from wild and farmed Atlantic salmon (Salmo salar L.) at two time points (early summer 1995 and summer 2009), and also those collected from wild sea trout (Salmo trutta 
L.) in summer 1996. Samples obtained in 2009 were used fresh whilst older samples were stored at $-80^{\circ} \mathrm{C}$ prior to use. The Atlantic salmon were all sampled in sea water mostly from various sea lochs whereas the sea trout was sampled in freshwater. Samples of L. hippoglossi collected from wild Atlantic halibut (Hippoglossus hippoglossus L.) in summer 1998 were also examined. All lice samples were adult females without egg strings. For three samples from farmed salmon, egg strings were carefully removed and also used for analysis.

Individual fresh or frozen lice were processed by macerating them in $30 \mu \mathrm{l}$ of homogenization buffer (1 Mm Tris-HCL, pH 7.0, 0.1 mM EDTA, 0.1mM 2-mercaptoethanol) using a pellet pestle (Anachem, Luton UK). Samples were then flash frozen in liquid nitrogen and stored at $-70{ }^{\circ} \mathrm{C}$ until required. Salmon muscle samples were skinned and boned white muscle fillets that were flash frozen in liquid nitrogen and stored at $-70{ }^{\circ} \mathrm{C}$ until required. The muscle samples were thawed and homogenized into a paté prior to lipid extraction.

\subsection{Lipid extraction}

Total lipid was prepared according to the method of Folch et al. (1957). Sea lice samples or $0.5 \mathrm{~g}$ samples of salmon muscle paté were added to $5 \mathrm{ml}$ ice cold chloroform/methanol (2:1, by volume) containing $0.01 \%$ butylated hydroxytoluene as an antioxidant, and were homogenized using an IKA Ultra-Turrax T8. Tubes of homogenate were left on ice for one hour. A further $1 \mathrm{ml}$ of chloroform/methanol (2:1, v/v) was then added along with $1.5 \mathrm{ml}$ aqueous $\mathrm{KCl}(0.88 \%)$. Samples were left on ice for a further $5 \mathrm{~min}$ and were then centrifuged at $600 \mathrm{~g}_{\text {ave }}$ for $5 \mathrm{~min}$ to separate the mixture. The lower organic layer was filtered through Whatman No. 1 filter paper into clean test tubes, the solvent evaporated under a stream of oxygen-free nitrogen (OFN) and the dry lipid extract re-suspended in chloroform/methanol $(2: 1, \mathrm{v} / \mathrm{v})$

\subsection{Lipid class composition analysis}

130 Lipid class separation was performed by high-performance thin-layer chromatography (HPTLC).

131 The concentration of the lipid extracts was adjusted to $10 \mathrm{mg} / \mathrm{ml}$ in chloroform/methanol $(2: 1, \mathrm{v} / \mathrm{v})$ 132 and two $\mu \mathrm{L}$ of each sample loaded as $2 \mathrm{~mm}$ streaks, $1 \mathrm{~cm}$ up on HPTLC plates $(10 \mathrm{~cm} \mathrm{x} 10 \mathrm{~cm} \mathrm{x}$ $1330.15 \mathrm{~mm}$ ), precoated with silica gel 60 (Merck, Darmstadt, Germany). The plate was developed to 134 approximately $5 \mathrm{~cm}$ with methyl acetate/isopropanol/chloroform/methanol/0.25\% aqueous $\mathrm{KCl}$ 135 (25:25:25:10:9, by vol.) then, after drying in air for $30 \mathrm{~min}$, developed fully with isohexane/diethyl 136 ether/acetic acid (85:15:1, by vol.). The lipid classes were visualized and quantified by charring at $137160{ }^{\circ} \mathrm{C}$ for $15 \mathrm{~min}$ after spraying with $3 \%(\mathrm{w} / \mathrm{v})$ aqueous cupric acetate containing $8 \%(\mathrm{v} / \mathrm{v})$ 138 phosphoric acid and quantified by densitometry using a Camag 3 TLC Scanner (Camag, Muttenz, 139 Switzerland) and winCATS software (Henderson and Tocher, 1992). The identities of individual 
140 lipid classes were confirmed by comparison with reference to the Rf values of authentic standards 141 run alongside samples on HPTLC plates and developed in the above solvent systems.

\subsection{Fatty acid composition analysis}

144 Fatty acid composition was determined by gas chromatography analysis of fatty acid methyl esters (FAME) prepared by acid-catalyzed transmethylation (Christie, 1993). Approximately $0.5 \mathrm{mg}$ of total lipid was taken into a clean test tube and the solvent evaporated under a stream of OFN before $1 \mathrm{ml}$ toluene and $2.5 \mathrm{ml}$ of $1 \% \mathrm{H}_{2} \mathrm{SO}_{4}$ in methanol were added and the sample incubated overnight at $50^{\circ} \mathrm{C}$ (Christie, 1993). After cooling, FAME were extracted by addition of $2 \mathrm{ml}$ of $2 \% \mathrm{KHCO}_{3}$ and $5 \mathrm{ml}$ of isohexane/diethyl ether $(1: 1, \mathrm{v} / \mathrm{v})$ containing $0.01 \%$ BHT, followed by thorough mixing and centrifugation at $600 \mathrm{~g}_{\mathrm{ave}}$ for $2 \mathrm{~min}$. The upper layer was removed into a clean test tube and the lower layer further extracted with a further portion of $5 \mathrm{ml}$ of isohexane/diethyl ether $(1: 1, \mathrm{v} / \mathrm{v})$ without BHT. After centrifugation at $600 \mathrm{~g}_{\text {ave }}$ for $2 \mathrm{~min}$, the upper layer was removed and added to the previous upper layer, and the solvent evaporated under a stream of OFN, before the crude FAME extract was resuspended in $100 \mu \mathrm{l}$ isohexane. The FAME were purified by thin-layer chromatography (TLC) prior to GC analysis. Samples were applied as $2 \mathrm{~cm}$ streaks to TLC plates $(20 \mathrm{~cm} \times 20 \mathrm{~cm} \times 0.25 \mathrm{~mm})$ and FAME separated from non-derivatized lipid classes using hexane/diethyl ether/acetic acid (90:10:1, by vol.) as developing solvent. The FAME were located on the plate by staining standards run at the side of the plate using an Iodine spray. The areas of silica containing FAME were scraped into clean test tubes and FAME eluted using isohexane/diethyl ether (1:1). After centrifugation the supernatant solvent was removed into a clean test tube, the solvent evaporated under OFN and the FAME resuspended in $200 \mu \mathrm{L}$ of isohexane. The FAME were separated and quantified by gas-liquid capillary chromatography using a Fisons capillary column (CP Wax 52CB, Chrompak Ltd., London, U.K.) and on-column injection. Hydrogen was used as carrier gas and temperature programming was from $50{ }^{\circ} \mathrm{C}$ to $150{ }^{\circ} \mathrm{C}$ at $40{ }^{\circ} \mathrm{C}$ $\mathrm{min}^{-1}$ and then to $230{ }^{\circ} \mathrm{C}$ at $2.0{ }^{\circ} \mathrm{C} \mathrm{min}{ }^{-1}$. Individual methyl esters were identified by comparison with known standards and by reference to published data (Ackman, 1980; Tocher and Harvie, 1988). Data were collected and processed using the Chromcard for Windows (Version 1.19) computer package (Thermoquest Italia S.p.A., Milan, Italy).

\section{5. Materials}

172 BHT was obtained from Sigma Chemical Co. (Poole, U.K.). HPTLC (10 cm x $10 \mathrm{~cm}$ x $0.15 \mathrm{~mm})$ and TLC $(20 \mathrm{~cm} \times 20 \mathrm{~cm} \times 0.25 \mathrm{~mm})$ plates, precoated with silica gel 60 (without fluorescent 
indicator) were obtained from Merck (Darmstadt, Germany). All solvents were HPLC grade and were obtained from Fisher Scientific UK (Loughborough, England).

\subsection{Statistical analysis}

All data are presented as means $\pm \mathrm{SD}(\mathrm{n}=3)$. The significance of differences between samples were determined by one-way analysis of variance (ANOVA) followed, where appropriate, by Tukey's comparison test (Zar, 1999). Percentage data and data that were identified as nonhomogeneous (Bartlett's test) were subjected to arcsine transformation before analysis. Differences were regarded as significant when $\mathrm{P}<0.05$.

\section{Results}

\subsection{Effect of location on lipid class and fatty acid compositions of sea lice from farmed salmon}

Triacylglycerol (TAG) was the major lipid class in salmon lice, constituting between $35-45 \%$ of total lipid with 9-13\% cholesterol. Similar amounts of the major polar lipids, phosphatidylcholine (PC) and phosphatidylethanolamine (PE) were seen, with lesser amounts of other phosphoglycerides such as phosphatidylserine (PS) and phosphatidylinositol (PI), and the major sphingolipid, sphingomyelin (Table 2). There were few major differences in lipid class composition between samples and, although TAG levels varied, no significant differences in TAG or the proportions of total polar and neutral lipids were apparent. Free fatty acids (FFA) varied between 8 and $11 \%$, but these values were possibly partly artifactual resulting from post-mortem lipolytic action during homogenization and storage.

The fatty acid composition of the lice was characterized by about $25 \%$ saturated fatty acids, predominantly 16:0, around $35 \%$ monounsaturated fatty acids, predominantly 18:1n-9, 2-3 \% n-6 polyunsaturated fatty acids (PUFA) including 20:4n-6 (ARA, arachidonic acid), and 27-32 \% n-3 PUFA (Table 3). No major differences between the fatty acid compositions of lice obtained from farmed salmon at different sites were observed. Saturated fatty acids (mainly16:0) showed little variation (23-25\%), whereas monounsaturated fatty acids (largely 18:1n-9) showed slightly more (30-40\%), although none of the differences were significant (Table 3). There was more variability in the levels of certain PUFA, particularly 18:2n-6 and the main n-3 long-chain polyunsaturated fatty acid (LC-PUFA), 22:6n-3 (DHA, docosahexaenoic acid) (Table 3). There were no significant differences in the levels of the other important LC-PUFA, ARA and 20:5n-3 (EPA, eicosapentaenoic acid) between lice from the different populations of farmed salmon (Table 3 ).

\subsection{Lipid class and fatty acid compositions of female sea lice and their egg strings}


Very clear differences between the relative lipid class compositions of females and the egg strings

209 were observed, with eggs containing significantly higher proportions of TAG and neutral lipids than 210 females (Table 4). Thus, the lipid in egg strings comprised $80 \%$ neutral lipid, predominantly TAG 211 at around $70 \%$ and around $7 \%$ cholesterol. Consequently the proportions of all polar lipid classes 212 were significantly lower in egg strings compared to females although the relative proportions were 213 similar with PC and PE predominating (Table 4).

214 Compared to the female lice, the fatty acid compositions of the egg strings were 215 characterized by higher proportions of monounsaturated fatty acids, particularly 18:1n-9 but also 216 20:1, and lower levels of total PUFA, specifically n-3 PUFA, particularly DHA (Table 5). Few 217 differences in fatty acid composition of the egg strings obtained from the different locations could 218 be discerned.

3.3. Effect of year of sampling on lipid class and fatty acid compositions of sea lice from wild and farmed salmon Irrespective of sampling time point, the lipid class compositions of lice obtained from farmed or wild salmon showed few differences (Table 6). Clear trends were apparent for higher cholesterol levels in lice obtained from farmed fish and also for lower levels of FFA in the 2009 samples (Table 6). Relatively few major effects of louse source (wild / farmed) or year were apparent in the fatty acid compositions of the sea lice. However, there was a clear trend for higher 18:2n-6 and 18:3n-3 in the lice from the farmed fish compared to lice from wild fish (Table 7). The farmed fish also tended to have lower 16:0, 16:1n-7 and EPA, and higher 22:1 and 20:4n-3 compared to the lice from wild salmon. The levels of 18:2n-6, 18:3n-3, 20:4n-3 and DHA were higher in lice from 230 farmed fish in 2009 compared to 1995 (Table 7). In contrast, there was essentially no difference in the fatty acid composition of lice obtained from wild salmon in 1995 and those samples obtained in 2009.

The host-parasite transfer of fatty acids can be observed by comparing the compositions of female lice, their egg strings and the muscle of host salmon (Table 8). The higher level of 18:2n-6 in the lice from farmed fish in 2009 is a reflection of the relatively high level of this fatty acid ( $>5$ $\%)$ in the salmon, and this fatty acid is also present in eggs. However, there are differences in the fatty acid compositions of the three samples. For instance the lice and eggs have generally higher saturated fatty acids and LC-PUFA (especially ARA and DHA), and lower monounsaturated fatty acids and C18 PUFA (18:2n-6 and 18:3n-3) compared to the salmon muscle (Table 8). Total phospholipids were characterized by higher percentages of n-3 PUFA, total PUFA and saturated fatty acids compared to TAG, whereas TAG showed higher proportions of monounsaturated fatty 
acids and n-6 PUFA (Table 9). This was the pattern in female lice, egg strings and salmon muscle, although it was most pronounced in the fish muscle.

\subsection{Lipid class and fatty acid compositions of sea lice from salmon, sea trout and halibut}

Essentially no differences in lipid class composition between L. salmonis obtained from wild salmon and wild sea trout were significant with the difference in lyso-PC (a lipolytic product of PC) probably being due to differences in sampling. In contrast, L. hippoglossi was characterized by significantly lower levels of TAG and total neutral lipids compared to L. salmonis samples (Table 10). This was also reflected in higher proportions of PC, PE and sphingomyelin in halibut lice (Table 10).

The halibut lice had generally lower levels of saturated fatty acids than lice obtained from salmon (Table 11). However, there was a very clear variation in the levels of 18:1n-9 and total monoenes between the louse species, with levels decreasing significantly from salmon to trout to halibut (Table 11). Other than 24:1n-9, all the monoenes were significantly lower in halibut lice compared to the salmonid lice. In contrast, the levels of n-6, n-3 and total PUFA were significantly higher in halibut lice compared to the salmonid lice (Table 11). Interestingly, the higher n-3 PUFA in halibut was entirely due to higher DHA as levels of EPA and 22:5n-3 were significantly lower in halibut lice compared to the salmonid lice.

\section{Discussion}

In many free-living copepods, periods of dietary surplus and extensive feeding, such as occurs during plankton blooms, may foster phases of rapid growth. In some habitats, however, such as those of polar regions, phytoplankton blooms have only short durations and so many animals build up significant stored lipid reserves to carry them through periods of low food availability. These stored reserves function to allow survival through dark winters with low primary production, and are also used for reproductive purposes. Such lipid storage has been particularly noted for many zooplankton species (Lee et al., 2006). TAG is by far the most common form of energy store in krill species (Lee et al., 2006) and, in addition, is used as the main lipid store in most fish and marine mammals such as seals. However, a peculiarity in many marine organisms, such as calanoid copepods, is the occurrence of wax esters (WEs) as the main lipid store (Lee et al., 2006). Wax esters comprise long-chain fatty acids esterified to long-chain alcohols and there has been considerable discussion as to their advantages as storage products. It is suggested that WEs are suited to use as long-term energy reserves while TAG can be used for short-term energy supplies, or that WEs may be used for buoyancy regulation (Lee et al., 2006). However, few animals have only WEs as the only storage lipid. In many cases, there will also be various levels of TAG present 
depending on developmental stage. The present study has confirmed sparse earlier data (Lee, 1975) suggesting that parasitic caligid copepods of the genus Lepeophtheirus sp. store their lipid essentially as TAG with only small, trace amounts of WE. This perhaps supports the hypothesis that WEs are only required for long-term storage as the utilization of stored lipid in the parasitic copepods will only be required over a short time period between fish hosts.

The major phospholipid classes (membrane lipids) in the sea lice were PC and PE as in fish and most animals in general, and there were no major differences in the relative percentages of these membrane lipids. The major difference in lipid class composition observed between different samples was in the proportion of neutral (storage) lipid, TAG (Tocher, 2003). The major fatty acids observed in sea lice and their egg strings were 16:0, 18:1n-9, EPA and DHA, with lesser amounts of 18:0, 16:1n-7, 20:1, ARA and 22:5n-3, which is a pattern characteristic of fish (Tocher, 2003). Therefore, the general fatty acid composition of lice is suggested to be a reflection of the fatty acid composition of the fish host.

Some of the differences in fatty acid composition observed between the samples were also reflective of the differences in lipid class composition discussed above. Neutral lipids like TAG generally have higher levels of monounsaturated fatty acids (monoenes) and lower PUFA as they are used primarily as an energy store, whereas phospholipids have higher PUFA as they are membrane lipids and PUFA are essential for membrane function, possibly in terms of membrane fluidity but more so for enzyme, receptor and carrier protein activities (Tocher, 2003). Lee (1975) reported the fatty acid composition of TAG and phospholipids from L. salmonis and showed that TAG had higher monoenes and lower PUFA than phospholipids. In the present study, this pattern was also clearly observed in the salmon muscle, female lice and egg string samples. Indeed all the samples in the present study that contained higher proportions of TAG were characterized by higher proportions of monoenes and lower proportions of PUFA and, especially, LC-PUFA. This was observed in the salmon louse versus egg string comparisons and also in the halibut versus salmonid lice comparisons.

It is probable, however, that the sea lice can modify the fatty acids obtained from the host. The adult female lice and the salmon muscle had similar levels of TAG (Table 8) but the sea lice showed lower levels of C18 PUFA, 18:2n-6 and 18:3n-3 and higher levels of the LC-PUFA ARA and DHA. This may indicate that they were able to convert the shorter chain fatty acids to the LCPUFA by fatty acid desaturation and elongation, or, alternatively, differences in PUFA composition could be generated by selective oxidation of C18 PUFA and selective retention of LC-PUFA in lice (Tocher, 2003). Previously, Lee (1975) reported that the DHA:EPA ratio in L. salmonis lipids were 2:1 in TAG and 6:1 in phospholipid. In the present study, the DHA:EPA ratios in L. salmonis and 
311 their egg strings were around 8:1 and 3:1 in phospholipids and TAG, respectively, and only 4:1 and $312 \quad 2: 1$ in salmon muscle phospholipids and TAG.

313 The fatty acid composition of fish, and animals in general, is most strongly influenced by 314 diet (Tocher, 2003). As salmon lice are considered to obtain all their nutrition from the fish host, 315 differences in the fatty acid composition of the diet of the fish host could similarly be reflected in 316 the composition of the lice, as observed in the present study. Thus, the fatty acid composition of lice 317 from farmed salmon in 2009 showed a difference compared to lice from farmed fish in 1995, 318 specifically in terms of increased levels of $18: 2 n-6$ and 18:3n-3. This is because feeds for salmon 319 farming are being changed to more sustainable formulations, in particular replacing the marine 320 resources, fishmeal and fish oil, global supplies of which are limiting, with more sustainable plant 321 meals and vegetable oils (Tacon and Metian, 2008). Currently, around $25 \%$ of fish meal and $50 \%$ 322 of fish oil is now generally substituted with plant alternatives in salmon feeds. Lipids in fishmeal 323 and fish oil have high EPA and DHA and low C18 PUFA whereas plant meals and oils contain no 324 LC-PUFA whatsoever, and high levels of C18 fatty acids, especially18:1n-9 and 18:2n-6 but also 325 18:3n-3 (Gunstone and Harwood, 2007). Therefore, the increased levels of C18 PUFA in the 326 farmed samples from 2009 were expected but it was surprising that levels of EPA and DHA were 327 maintained. This may be due to the specific fish oil included in the diets, as fish oils with higher 328 LC-PUFA sourced from the southern hemisphere, may act to compensate for reduced levels of fish 329 oil in the feed (Pratoomyot et al., 2008). In contrast, no differences in fatty acid compositions of lice 330 from farmed and wild salmon were observed in 1995 samples due to fact that salmon feeds at that 331 time comprised almost exclusively fishmeal and fish oil and, therefore, farmed fish would be 332 getting essentially the same diet (fish) as the wild fish. Similarly, no difference was observed in the 333 fatty acid composition of lice from wild fish sampled in 1995 and 2009. Differences in sea louse 334 composition resulting from changes in salmon feed components may not be simply of academic 335 interest. It is recognised, for instance, that L. salmonis secretes immuno-modulatory products 336 including the prostaglandin $\mathrm{E}_{2}$ (Fast et al., 2004), a derivative of the omega- 6 fatty acid ARA, 337 which may function to protect the parasite from the host's immune response. Changes in the fatty 338 acid profile of the parasite could therefore potentially affect, in a positive or negative fashion, the 339 interaction between parasite and host, leading to changes in infection intensity and / or host injury.

340 In conclusion, the present study has confirmed that parasitic caligid copepods of the genus 341 Lepeophtheirus store their lipid essentially as TAG. Egg strings had higher lipid contents than adult 342 female lice and this was reflected in higher TAG levels. Differences in fatty acid composition 343 observed between the samples partly reflected the differences in lipid content and TAG levels but it 344 is also likely that the endogenous metabolism of the lice modifies their fatty acid composition. 345 Changes in the fatty acid composition of salmon feeds is reflected in the fatty acid composition of 
the lice and their egg strings and this may have consequences for the ability of lice to suppress the host's immune response. The fact that changes to the lipid and fatty acid composition of feeds for farmed salmon influence the composition of sea lice indicates that further investigation of lipid and fatty acid metabolism of $L$. salmonis is warranted.

\section{Acknowledgement}

JAT was supported by a Nuffield Science Bursary from The Nuffield Foundation.

\section{References}

Ackman R.G., 1980. Fish lipids. In: Advances in Fish Science and Technology (ed. by J.J. Connell), pp. 87-103. Fishing News Books, Farnham.

Boxaspen, K., 2006. A review of the biology and genetics of sea lice. ICES J. Mar. Sci. 63, 13041316.

Brandal, P.O., Egidius, E., Romslo, I., 1976. Host blood: a major food component for the parasitic copepod Lepeophtheirus salmonis, Krøyer, 1838 (Crustacea: Caligidae). Nor. J. Zool. 24, 341343.

Christie W.W., 1993. Preparation of derivatives of fatty acids for chromatographic analysis. In: Christie, W.W. (Ed.), Advances in Lipid Methodology - Two. The Oily Press, Dundee. pp.69111.

Costello, M.J., 2009. The global economic cost of sea lice to the salmonid farming industry. J. Fish Dis. $32,115-118$.

Falk-Petersen, S., Mayzaud, P., Kattner, G., Sargent, J. 2009. Lipids and life strategy of Arctic Calanus. Marine Biology Research, 5, 18-39.

Fast, M.D., Ross, N.W., Craft, C.A., Locke, S.J., MacKinnon, S.L., Johnson, S.C., 2004. Lepeophtheirus salmonis: characterization of prostaglandin E-2 in secretory products of the salmon louse by Rp-HPLC and mass spectrometry. Exp. Parasitol. 107, 5-13.

Folch, J., Lees, M., Sloane-Stanley, G.H., 1957. A simple method for the isolation and purification of total lipids from animal tissues. J. Biol. Chem. 226, 497-509.

Ford, J.S., Myers, R.A., 2008. A global assessment of salmon aquaculture impacts on wild salmonids. PLoS Biology 6, e33.

Gunstone, F.D., Harwood, J.L., 2007. Occurrence and characteristics of oils and fats. In: The Lipid Handbook (Gunstone, F.D., Harwood, J.L. and Dijkstra, A.J., Eds.) pp.37-142. CRC Press, Taylor \& Francis, London. 
Henderson, R.J., Tocher, D.R., 1992. Thin-layer chromatography. In: Lipid Analysis: A Practical Approach (ed. by R.J. Hamilton and S. Hamilton), pp. 65-111. IRL Press, Oxford, UK.

Jonsdottir, H., Bron, J.E., Wootten, R., Turnbull, J.T., 1992. The histopathology associated with the preadult and adult stages of Lepeophtheirus salmonis on the Atlantic salmon Salmo salar L. J. Fish Dis. 15, 521-527.

Johnson, S.C., Treasurer, J.W., Bravo, S., Nagasawa, K., Kabata, Z., 2004. A review of the impact of parasitic copepods on marine aquaculture. Zoological Studies 43, 229-243.

Kabata, Z., 1979. Parasitic Copepoda of British Fishes. Ray Society, London. 468 pp.

Kattner, G. and Krause, M. 1989. Seasonal variations of lipids (wax esters, fatty acids and alcohols) in Calanoid copepods from the North Sea. Mar. Chem., 26, 261-275.

Kattner, G., Hagen, W., Lee, R.F., Campbell, R., Deibel, D., Falk-Petersen, S., Graeve, M., Hansen, B.W., Hirche, H.J., Jonasdottir, S.H., Madsen, M.L., Mayzaud, P., Muller-Navarra, D., Nichols, P.D., Paffenhofer, G.-A., Pond, D., Saito, H., Stubing, D., Virtue, P., 2007. Perspectives on marine zooplankton lipids. Can. J. Fish. Aquat. Sci. 64, 1628-1639.

Lee, R.F., 1975. Lipids of parasitic copepods associated with marine fish. Comp. Biochem. Physiol. 52B, 363-364.

Lee, R.F., Hagen, W., Kattner, G., 2006. Lipid storage in marine zooplankton. Mar. Ecol. Prog. Ser. 307, 273-306.

Pike, A.W., Wadsworth, S.L., 1999. Sealice on salmonids: Their biology and control. Adv. Parasitol. 44, 233-337.

Pratoomyot, J., Bendiksen, E.Å., Bell, J.G., Tocher, D.R., 2008. Comparison of effects of blended vegetable oils and contaminant-stripped fish oil on growth performance, composition, and gene expression in Atlantic salmon (Salmo salar L.). Aquaculture 280, 170-178.

Ritchie, G., 1997. The host transfer ability of Lepeophtheirus salmonis (Copepoda: Caligidae) from farmed Atlantic salmon, Salmo salar L. J. Fish Dis. 20, 153-157.

Rohde, K. (ed.), 2005. Marine Parasitology. CSRIO Publishing-CABI, Collingwood, Australia, $565 \mathrm{p}$.

Schram, T.A., Supplemental descriptions of the developmental stages of Lepeophtheirus salmonis (Krøyer, 1837) (Copepoda: Caligidae). In Boxshall, G.A., Defaye, D. (Eds)., Pathogens of Wild and Farmd Fish: Sea Lice . Ellis Horwood: New York, pp. 30-47.

Skjoldal, H.R., Dalpadado, P., Dommasnes, A. 2004. Food webs and trophic interactions. In: Skjoldal, H. R., Sætre, R., Færnø, A., Misund, O. A., Røttingen, I. (Eds.), The Norwegian Sea Ecosystem. Trondheim, Norway: Tapir Academic Press. 447-506.

Tacon, A.G.J., Meitan, M., 2008. Global overview on the use of fish meal and fish oil in industrially compounded aquafeeds: Trends and future prospecs. Aquaculture 285, 146-158. 
415 Tocher D.R., 2003. Metabolism and functions of lipids and fatty acids in teleost fish. Rev. Fisheries $416 \quad$ Sci. $11,107-184$.

417 Tocher, D.R., Harvie, D.G., 1988. Fatty acid compositions of the major phosphoglycerides from 418 fish neural tissues : (n-3) and (n-6) polyunsaturated fatty acids in rainbow trout (Salmo 419 gairdneri, L.) and cod (Gadus morhua) brains and retinas. Fish Physiol. Biochem. 5, 229$420 \quad 239$.

421 Tucker, C., Sommerville, C., Wootten, R., 2000. An investigation onto the larval energetics and 422 settlement of sea louse, Lepeophtheirus salmonis, an ectoparasitic copepod of Atlantic salmon, 423 Salmo salar. Fish Path. 35, 137-143.

424 Zar J.H., 1999. Biostatistical Analysis $4^{\text {th }}$ Edition; Prentice-Hall; Upper Saddle River, New Jersey. 425 
Table 1. Details of the Lepeophtheirus von Nordmann, 1832 samples collected in Scottish waters and used for the current study.

\begin{tabular}{|c|c|c|c|c|}
\hline Species & Host & Locality (date) & Latitude / longitude & Samples analysed \\
\hline $\begin{array}{l}\text { Lepeophtheirus hippoglossi } \\
\text { (Krøyer, 1837) }\end{array}$ & Hippoglossus hippoglossus L. (W) & North Atlantic (06/98) & $58^{\circ} 52^{\prime} 56.87^{\prime \prime} \mathrm{N} / 7^{\circ} 27^{\prime} 04.63^{\prime \prime} \mathrm{W}$ & Adult female lice (S) \\
\hline \multirow{12}{*}{$\begin{array}{l}\text { Lepeophtheirus salm } \\
\text { (Krøyer, 1837) }\end{array}$} & Salmo trutta L. (W) & River Ewe (07/96) & $57^{\circ} 50^{\prime} 23.43^{\prime \prime} \mathrm{N} / 5^{\circ} 3456.21 \mathrm{~W}$ & Adult female lice (S) \\
\hline & Salmo salar L. (W) & Loch Duich $(06 / 95)$ & $57^{\circ} 13^{\prime} 48.41^{\prime \prime} \mathrm{N} / 5^{\circ} 28^{\prime} 02.04 ” \mathrm{~W}$ & Adult female lice (S) \\
\hline & & Armadale, Skye (06/09) & $57^{\circ} 03^{\prime} 30.90^{\prime \prime} \mathrm{N} / 5^{\circ} 53^{\prime} 09.19^{\prime \prime} \mathrm{W}$ & Adult female lice (NS) \\
\hline & Salmo salar L. (F) & Loch Duich $(06 / 95)$ & $57^{\circ} 14^{\prime} 49.70^{\prime \prime} \mathrm{N} / 5^{\circ} 29^{\prime} 00.19^{\prime \prime} \mathrm{W}$ & Adult female lice (S) \\
\hline & & Loch Fyne (site 2; 04/95) & $56^{\circ} 13^{\prime} 40.35^{\prime \prime} \mathrm{N} / 502{ }^{\prime} 30.38^{\prime \prime} \mathrm{W}$ & Adult female lice (S) \\
\hline & & Loch Fyne (site $1 ; 05 / 95$ ) & $56^{\circ} 04^{\prime} 02.78^{\prime \prime} \mathrm{N} / 517^{\prime} 25.78^{\prime \prime} \mathrm{W}$ & Eggstrings \\
\hline & & Loch na Keal, Mull (06/95) & $56^{\circ} 26^{\prime} 02.05^{\prime \prime} \mathrm{N} / 6^{\circ} 12^{\prime} 13.94 ” \mathrm{~W}$ & Adult female lice (S) \\
\hline & & Loch Linnhe $(04 / 95)$ & $56^{\circ} 31^{\prime} 38.61^{\prime \prime} \mathrm{N} / 5^{\circ} 32^{\prime} 42.41^{\prime \prime} \mathrm{W}$ & Adult female lice (S) \\
\hline & & Lumlash Bay, Arran (05/95) & $55^{\circ} 31^{\prime} 48.38^{\prime \prime} \mathrm{N} / 5^{\circ} 06^{\prime} 15.2^{\prime \prime} \mathrm{W}$ & Adult female lice (S) \\
\hline & & Lumlash Bay, Arran (05/95) & $55^{\circ} 31^{\prime} 48.38^{\prime \prime} \mathrm{N} / 5^{\circ} 06^{\prime} 15.2^{\prime \prime} \mathrm{W}$ & Eggstrings \\
\hline & & Shuna (04/95) & $56^{\circ} 13^{\prime} 49.68^{\prime \prime} \mathrm{N} / 5^{\circ} 35^{\prime} 20.15^{\prime \prime} \mathrm{W}$ & Eggstrings \\
\hline & & Machrihanish (07/09) & $55^{\circ} 25^{\prime} 24.45^{\prime \prime} \mathrm{N} / 5^{\circ} 44^{\prime} 54.40^{\prime \prime} \mathrm{W}$ & Adult female lice (S) \\
\hline
\end{tabular}

F, Farmed; NS, not starved; S, starved for 24 hrs prior to processing; W, wild. 
Table 2. Lipid class composition (percentage of total lipid) of L. salmonis obtained from Atlantic salmon farmed at various locations.

\begin{tabular}{lccccccc}
\hline Lipid class & Duich & Linnhe & Mull & Arran & Shuna & Fyne \\
\hline PC & $13.5 \pm 2.9$ & $14.3 \pm 1.5$ & $14.6 \pm 2.6$ & $12.7 \pm 0.3$ & $12.6 \pm 1.3$ & $15.9 \pm 0.9$ \\
PE & $14.2 \pm 1.8$ & $12.2 \pm 3.8$ & $13.3 \pm 0.9$ & $10.8 \pm 2.0$ & $12.6 \pm 1.9$ & $14.6 \pm 0.9$ \\
PS/PI/PA/CL & $9.9 \pm 1.9$ & $7.8 \pm 2.8$ & $10.1 \pm 3.8$ & $7.7 \pm 1.6$ & $7.4 \pm 2.7$ & $8.0 \pm 1.6$ \\
Sphingomyelin & $3.5 \pm 1.2$ & $4.4 \pm 0.9$ & $3.5 \pm 1.9$ & $3.2 \pm 0.3$ & $2.9 \pm 0.8$ & $4.2 \pm 0.2$ \\
LPC & $0.5 \pm 0.3 \mathrm{~b}$ & $0.2 \pm 0.2 \mathrm{~b}$ & $0.8 \pm 0.3$ ab & $1.2 \pm 0.1 \mathrm{a}$ & $0.7 \pm 0.2$ ab & $0.7 \pm 0.2$ ab \\
Total polar & $41.5 \pm 7.4$ & $38.9 \pm 5.0$ & $42.2 \pm 8.5$ & $35.6 \pm 3.5$ & $36.2 \pm 6.7$ & $43.4 \pm 2.5$ \\
Total neutral & $58.5 \pm 7.4$ & $61.1 \pm 5.0$ & $57.8 \pm 8.5$ & $64.4 \pm 3.5$ & $63.8 \pm 6.7$ & $56.6 \pm 2.5$ \\
Cholesterol & $13.3 \pm 0.8{ }^{\mathrm{a}}$ & $10.8 \pm 1.1$ ab & $12.7 \pm 1.6$ a & $8.7 \pm 0.5 \mathrm{~b}$ & $11.7 \pm 2.0$ ab & $10.9 \pm 0.6$ ab \\
Triacylglycerol & $34.7 \pm 8.4$ & $40.8 \pm 5.7$ & $36.0 \pm 10.6$ & $45.4 \pm 5.3$ & $44.4 \pm 6.5$ & $35.0 \pm 3.2$ \\
Free fatty acid & $10.4 \pm 1.8$ & $9.4 \pm 0.6$ & $9.1 \pm 3.4$ & $10.2 \pm 1.4$ & $7.7 \pm 1.4$ & $10.7 \pm 2.7$ \\
Steryl/wax ester & Trace & Trace & Trace & Trace & Trace & Trace \\
\hline
\end{tabular}

Results are means \pm SD $(n=3)$. Values within a row with different superscript letters are significantly different $(P<0.05)$.

CL, cardiolipin; LPC, lyso-PC; PA, phosphatidic acid; PC, phosphatidylcholine; PE, phosphatidylethanolamine;

PI, phosphatidylinositol; PS, phosphatidylserine. 
Table 3. Fatty acid composition (percentage of total fatty acids) of L. salmonis obtained from Atlantic salmon farmed at various locations.

\begin{tabular}{|c|c|c|c|c|c|c|}
\hline Fatty acid & Duich & Linnhe & Mull & Arran & Shuna & Fyne \\
\hline $14: 0$ & $2.1 \pm 0.0^{b}$ & $2.5 \pm 0.2^{b}$ & $2.2 \pm 0.3^{b}$ & $2.4 \pm 0.2^{b}$ & $2.4 \pm 0.2^{b}$ & $3.1 \pm 0.1^{a}$ \\
\hline $16: 0$ & $17.9 \pm 0.5$ & $17.1 \pm 2.8$ & $16.8 \pm 0.7$ & $17.1 \pm 0.9$ & $16.6 \pm 0.9$ & $16.9 \pm 1.9$ \\
\hline $18: 0$ & $3.9 \pm 0.5$ & $3.7 \pm 0.8$ & $3.7 \pm 0.2$ & $3.4 \pm 0.3$ & $2.9 \pm 0.3$ & $3.9 \pm 0.9$ \\
\hline Total saturated ${ }^{1}$ & $25.4 \pm 0.9$ & $24.1 \pm 3.6$ & $23.5 \pm 1.0$ & $23.5 \pm 0.5$ & $22.6 \pm 0.6$ & $25.0 \pm 3.5$ \\
\hline $16: \ln -9$ & $1.7 \pm 0.4$ & $1.8 \pm 1.2$ & $2.1 \pm 0.3$ & $2.0 \pm 0.2$ & $2.2 \pm 0.5$ & $3.0 \pm 0.1$ \\
\hline $16: \ln -7$ & $2.3 \pm 0.2^{b}$ & $3.1 \pm 1.1^{\mathrm{ab}}$ & $2.7 \pm 0.3^{a b}$ & $3.1 \pm 0.2^{a b}$ & $3.7 \pm 0.4^{\mathrm{ab}}$ & $3.6 \pm 0.1^{a}$ \\
\hline $18: \ln -9$ & $22.5 \pm 2.5^{\mathrm{ab}}$ & $24.8 \pm 3.2^{a b}$ & $23.2 \pm 3.7^{\mathrm{ab}}$ & $28.2 \pm 1.9^{a}$ & $25.4 \pm 2.7^{\mathrm{ab}}$ & $19.0 \pm 3.7^{b}$ \\
\hline $18: \ln -7$ & $1.4 \pm 0.2$ & $1.4 \pm 0.0$ & $1.3 \pm 0.3$ & $1.6 \pm 0.1$ & $1.4 \pm 0.2$ & $1.5 \pm 0.3$ \\
\hline $20: 1^{2}$ & $2.8 \pm 0.5$ & $2.9 \pm 0.3$ & $2.2 \pm 0.2$ & $2.7 \pm 0.2$ & $2.4 \pm 0.1$ & $2.6 \pm 0.1$ \\
\hline $22: 1^{3}$ & $2.1 \pm 0.4^{\mathrm{a}}$ & $1.0 \pm 0.1^{\mathrm{b}}$ & $1.1 \pm 0.3^{b}$ & $1.0 \pm 0.1^{\mathrm{b}}$ & $1.3 \pm 0.1^{b}$ & $1.4 \pm 0.5^{a b}$ \\
\hline $24: 1 n-9$ & $2.5 \pm 1.2^{\mathrm{a}}$ & $1.7 \pm 0.1^{\mathrm{ab}}$ & $1.2 \pm 0.0^{\mathrm{b}}$ & $0.9 \pm 0.2^{b}$ & $0.9 \pm 0.1^{\mathrm{b}}$ & $0.7 \pm 0.3^{b}$ \\
\hline Total monoenes & $35.2 \pm 3.2$ & $36.6 \pm 4.8$ & $33.8 \pm 4.0$ & $39.6 \pm 1.6$ & $37.3 \pm 2.2$ & $30.0 \pm 5.3$ \\
\hline $18: 2 n-6$ & $1.0 \pm 0.1^{\mathrm{ab}}$ & $0.4 \pm 0.0^{\mathrm{d}}$ & $1.2 \pm 0.1^{\mathrm{a}}$ & $0.8 \pm 0.0^{b c}$ & $0.6 \pm 0.0^{\mathrm{cd}}$ & $1.4 \pm 0.4^{\mathrm{a}}$ \\
\hline $20: 4 n-6$ & $1.2 \pm 0.4$ & $1.0 \pm 0.1$ & $1.0 \pm 0.4$ & $1.3 \pm 0.2$ & $0.9 \pm 0.1$ & $0.9 \pm 0.1$ \\
\hline Total n-6PUFA ${ }^{4}$ & $2.9 \pm 0.5^{\mathrm{a}}$ & $2.0 \pm 0.1^{b}$ & $2.6 \pm 0.5^{\mathrm{ab}}$ & $2.6 \pm 0.3^{\mathrm{ab}}$ & $1.8 \pm 0.1^{b}$ & $2.8 \pm 0.3^{a}$ \\
\hline $18: 3 n-3$ & $0.3 \pm 0.0^{b c}$ & $0.3 \pm 0.0^{\mathrm{bc}}$ & $0.5 \pm 0.0^{\mathrm{c}}$ & $0.3 \pm 0.0^{b c}$ & $0.4 \pm 0.0^{\mathrm{b}}$ & $0.7 \pm 0.2^{a}$ \\
\hline $20: 4 n-3$ & $0.6 \pm 0.1^{\mathrm{ab}}$ & $0.4 \pm 0.2^{b}$ & $0.7 \pm 0.1^{b}$ & $0.7 \pm 0.1^{\mathrm{ab}}$ & $0.8 \pm 0.1^{\mathrm{a}}$ & $0.6 \pm 0.1^{a b}$ \\
\hline $20: 5 n-3$ & $4.3 \pm 0.8$ & $4.6 \pm 1.1$ & $4.8 \pm 0.6$ & $4.7 \pm 0.1$ & $5.2 \pm 0.2$ & $4.0 \pm 0.4$ \\
\hline $22: 5 n-3$ & $3.0 \pm 0.5^{a b}$ & $2.5 \pm 0.9^{b}$ & $3.5 \pm 0.4^{\mathrm{a}}$ & $3.3 \pm 0.6^{\mathrm{ab}}$ & $3.0 \pm 0.3^{\mathrm{ab}}$ & $2.3 \pm 0.7^{b}$ \\
\hline $22: 6 n-3$ & $18.4 \pm 3.1^{b}$ & $20.8 \pm 4.6^{a b}$ & $25.3 \pm 3.4^{\mathrm{ab}}$ & $20.6 \pm 0.4^{a b}$ & $23.0 \pm 0.8^{a b}$ & $25.8 \pm 2.0^{\mathrm{a}}$ \\
\hline Total n-3PUFA ${ }^{5}$ & $26.9 \pm 4.5$ & $28.8 \pm 6.0$ & $35.1 \pm 3.7$ & $29.9 \pm 0.8$ & $32.7 \pm 0.2$ & $33.6 \pm 3.0$ \\
\hline Total PUFA & $29.7 \pm 4.5$ & $30.8 \pm 6.0$ & $37.7 \pm 3.7$ & $32.5 \pm 1.1$ & $34.5 \pm 0.1$ & $36.4 \pm 2.8$ \\
\hline
\end{tabular}

Results are means $\pm \mathrm{SD}(\mathrm{n}=3)$. Values within a row with different superscript letters are significantly different $(\mathrm{P}<0.05)$.

${ }^{1}$, Totals include 15:0, 20:0 and 22:0 present in some samples at up to $0.7 \%$; $^{2}$, Predominantly n-9 isomer;

${ }^{3}$, Predominantly n-11 isomer; ${ }^{4}$, Totals include 18:3n-6, 20:2n-6,20:3n-6, 22:4n-6 and 22:5n-6 present in some samples at up to $0.3 \%$; ${ }^{5}$, Totals include $18: 3 n-3$ and $20: 3 n-3$ present in some samples at up to $0.2 \%$; PUFA, polyunsaturated fatty acids. 
Table 4. Lipid class compositions (percentage of total lipid) of L. salmonis females and their egg strings

\begin{tabular}{|c|c|c|c|c|c|c|}
\hline \multirow[b]{2}{*}{ Lipid class } & \multicolumn{3}{|c|}{ Females } & \multicolumn{3}{|c|}{ Egg strings } \\
\hline & Arran & Shuna & Fyne & Arran & Shuna & Fyne \\
\hline $\mathrm{PC}$ & $12.7 \pm 0.3^{a}$ & $12.6 \pm 1.3^{a}$ & $15.9 \pm 0.9^{a}$ & $8.7 \pm 0.8^{b}$ & $9.3 \pm 0.9^{\mathrm{b}}$ & $9.6 \pm 0.8^{b}$ \\
\hline PE & $10.8 \pm 2.0^{a}$ & $12.6 \pm 1.9^{a}$ & $14.6 \pm 0.9^{a}$ & $6.4 \pm 0.1^{\mathrm{b}}$ & $5.9 \pm 0.6^{\mathrm{b}}$ & $6.4 \pm 1.6^{b}$ \\
\hline $\mathrm{PS} / \mathrm{PI} / \mathrm{PA} / \mathrm{CL}$ & $7.7 \pm 1.6^{\mathrm{a}}$ & $7.4 \pm 2.7^{\mathrm{a}}$ & $8.0 \pm 1.6^{\mathrm{a}}$ & $4.5 \pm 0.7^{\mathrm{ab}}$ & $2.8 \pm 1.7^{\mathrm{b}}$ & $2.5 \pm 0.7^{\mathrm{b}}$ \\
\hline Sphingomyelin & $3.2 \pm 0.3^{a}$ & $2.9 \pm 0.8^{a}$ & $4.2 \pm 0.2^{\mathrm{a}}$ & $1.4 \pm 0.3^{\mathrm{b}}$ & $1.6 \pm 0.2^{\mathrm{b}}$ & $1.5 \pm 0.2^{b}$ \\
\hline LPC & $1.2 \pm 0.1$ & $0.7 \pm 0.2$ & $0.7 \pm 0.2$ & $0.3 \pm 0.2$ & $0.2 \pm 0.3$ & $0.5 \pm 0.8$ \\
\hline Total polar & $35.6 \pm 3.5^{\mathrm{a}}$ & $36.2 \pm 6.7^{a}$ & $43.4 \pm 2.5^{\mathrm{a}}$ & $21.2 \pm 0.2^{b}$ & $19.7 \pm 2.1^{b}$ & $20.5 \pm 2.5^{b}$ \\
\hline Total neutral & $64.4 \pm 3.5^{\mathrm{b}}$ & $63.8 \pm 6.7^{b}$ & $56.6 \pm 2.5^{b}$ & $78.8 \pm 0.2^{\mathrm{a}}$ & $80.3 \pm 2.1^{a}$ & $79.5 \pm 2.5^{a}$ \\
\hline Cholesterol & $8.7 \pm 0.5^{b}$ & $11.7 \pm 2.0^{\mathrm{a}}$ & $10.9 \pm 0.6^{\mathrm{a}}$ & $7.0 \pm 0.4^{b}$ & $7.1 \pm 0.2^{b}$ & $6.6 \pm 0.1^{b}$ \\
\hline Triacylglycerol & $45.4 \pm 5.3^{b}$ & $44.4 \pm 6.5^{b}$ & $35.0 \pm 3.2^{b}$ & $67.1 \pm 2.3^{\mathrm{a}}$ & $70.2 \pm 3.8^{a}$ & $69.3 \pm 3.0^{\mathrm{a}}$ \\
\hline Free fatty acid & $10.2 \pm 1.4^{\mathrm{a}}$ & $7.7 \pm 1.4$ ab & $10.7 \pm 2.7^{\mathrm{a}}$ & $4.7 \pm 2.0 \mathrm{bc}$ & $3.1 \pm 1.5^{\mathrm{c}}$ & $3.5 \pm 0.7^{\mathrm{c}}$ \\
\hline Steryl/wax ester & Trace & Trace & Trace & Trace & Trace & Trace \\
\hline
\end{tabular}

Results are means $\pm \mathrm{SD}(\mathrm{n}=3)$. Values within a row with different superscript letters are significantly different $(\mathrm{P}<0.05)$.

CL, cardiolipin; LPC, lyso-PC; PA, phosphatidic acid; PC, phosphatidylcholine; PE, phosphatidylethanolamine;

PI, phosphatidylinositol; PS, phosphatidylserine. 
Table 5. Fatty acid compositions (percentage of total fatty acids) of L. salmonis females and their egg strings

\begin{tabular}{|c|c|c|c|c|c|c|}
\hline \multirow[b]{2}{*}{ Fatty acid } & \multicolumn{3}{|c|}{ Females } & \multicolumn{3}{|c|}{ Egg strings } \\
\hline & Arran & Shuna & Fyne & Arran & Shuna & Ardcastle \\
\hline $14: 0$ & $2.4 \pm 0.2^{b}$ & $2.4 \pm 0.2^{b}$ & $3.1 \pm 0.1^{\mathrm{a}}$ & $2.4 \pm 0.2^{b}$ & $2.5 \pm 0.2^{b}$ & $1.5 \pm 0.1^{\mathrm{c}}$ \\
\hline $16: 0$ & $17.1 \pm 0.9^{a b}$ & $16.6 \pm 0.9^{a b}$ & $16.9 \pm 1.9^{a b}$ & $17.4 \pm 1.4^{\mathrm{a}}$ & $16.9 \pm 0.7^{\mathrm{ab}}$ & $14.5 \pm 0.8^{b}$ \\
\hline $18: 0$ & $3.4 \pm 0.3$ & $2.9 \pm 0.3$ & $3.9 \pm 0.9$ & $3.2 \pm 0.3$ & $2.9 \pm 0.1$ & $3.4 \pm 0.3$ \\
\hline Total saturated $^{1}$ & $23.5 \pm 0.5^{a b}$ & $22.6 \pm 0.6^{\mathrm{ab}}$ & $25.0 \pm 3.5^{\mathrm{a}}$ & $24.3 \pm 2.6^{\mathrm{a}}$ & $23.2 \pm 1.0^{\mathrm{ab}}$ & $19.9 \pm 1.3^{b}$ \\
\hline $16: \ln -9$ & $2.0 \pm 0.2^{b}$ & $2.2 \pm 0.5^{b}$ & $3.0 \pm 0.1^{\mathrm{a}}$ & $1.7 \pm 0.1^{\mathrm{b}}$ & $2.0 \pm 0.4^{\mathrm{b}}$ & $1.8 \pm 0.1^{b}$ \\
\hline $16: 1 n-7$ & $3.1 \pm 0.2^{b}$ & $3.7 \pm 0.4^{a b}$ & $3.6 \pm 0.1^{\mathrm{ab}}$ & $3.5 \pm 0.1^{\mathrm{ab}}$ & $3.9 \pm 0.2^{a}$ & $3.6 \pm 0.3^{\mathrm{ab}}$ \\
\hline $18: \ln -9$ & $28.2 \pm 1.9^{a b}$ & $25.4 \pm 2.7^{b}$ & $19.0 \pm 3.7^{b}$ & $30.5 \pm 0.7^{a}$ & $30.9 \pm 1.9^{\mathrm{a}}$ & $30.7 \pm 0.4^{\mathrm{a}}$ \\
\hline $18: 1 n-7$ & $1.6 \pm 0.1^{\mathrm{b}}$ & $1.4 \pm 0.2^{b}$ & $1.5 \pm 0.3^{b}$ & $1.7 \pm 0.1^{\mathrm{b}}$ & $1.5 \pm 0.2^{b}$ & $2.1 \pm 0.0^{\mathrm{a}}$ \\
\hline $20: 1^{2}$ & $2.7 \pm 0.2^{b c}$ & $2.4 \pm 0.1^{\mathrm{c}}$ & $2.6 \pm 0.1^{b c}$ & $3.2 \pm 0.1^{\mathrm{ab}}$ & $3.2 \pm 0.2^{a b}$ & $3.5 \pm 0.3^{a}$ \\
\hline $22: 1^{3}$ & $1.0 \pm 0.1$ & $1.3 \pm 0.1$ & $1.4 \pm 0.5$ & $1.1 \pm 0.5$ & $1.4 \pm 0.2$ & $1.1 \pm 0.1$ \\
\hline $24: 1 n-9$ & $0.9 \pm 0.2$ & $0.9 \pm 0.1$ & $0.7 \pm 0.3$ & $0.9 \pm 0.1$ & $1.0 \pm 0.2$ & $1.1 \pm 0.3$ \\
\hline Total monoenes & $39.6 \pm 1.6^{b c}$ & $37.3 \pm 2.2^{\mathrm{c}}$ & $30.0 \pm 5.3^{\mathrm{c}}$ & $42.6 \pm 0.4^{\mathrm{ab}}$ & $43.9 \pm 2.3^{a b}$ & $44.0 \pm 0.6^{\mathrm{a}}$ \\
\hline $18: 2 n-6$ & $0.8 \pm 0.0^{b}$ & $0.6 \pm 0.0^{\mathrm{b}}$ & $1.4 \pm 0.4^{\mathrm{a}}$ & $0.7 \pm 0.0^{b}$ & $0.5 \pm 0.0^{b}$ & $0.7 \pm 0.0^{b}$ \\
\hline $20: 4 n-6$ & $1.3 \pm 0.2^{\mathrm{ab}}$ & $0.9 \pm 0.1^{\mathrm{c}}$ & $0.9 \pm 0.1^{\mathrm{c}}$ & $1.4 \pm 0.1^{\mathrm{a}}$ & $1.0 \pm 0.1^{b c}$ & $1.5 \pm 0.2^{\mathrm{a}}$ \\
\hline Total n-6PUFA ${ }^{4}$ & $2.6 \pm 0.3^{b}$ & $1.8 \pm 0.1^{\mathrm{c}}$ & $2.8 \pm 0.3^{\mathrm{ab}}$ & $2.6 \pm 0.2^{b}$ & $1.8 \pm 0.1^{\mathrm{c}}$ & $3.1 \pm 0.1^{\mathrm{a}}$ \\
\hline $18: 3 n-3$ & $0.3 \pm 0.0^{b}$ & $0.4 \pm 0.0^{b}$ & $0.7 \pm 0.2^{a}$ & $0.4 \pm 0.0^{b}$ & $0.3 \pm 0.0^{\mathrm{b}}$ & $0.3 \pm 0.0^{b}$ \\
\hline $20: 4 n-3$ & $0.7 \pm 0.1$ & $0.8 \pm 0.1$ & $0.6 \pm 0.1$ & $0.7 \pm 0.1$ & $0.7 \pm 0.1$ & $0.6 \pm 0.1$ \\
\hline $20: 5 n-3$ & $4.7 \pm 0.1$ & $5.2 \pm 0.2$ & $4.0 \pm 0.4$ & $4.8 \pm 0.3$ & $5.1 \pm 0.5$ & $5.2 \pm 0.8$ \\
\hline $22: 5 n-3$ & $3.3 \pm 0.6$ & $3.0 \pm 0.3$ & $2.3 \pm 0.7$ & $2.5 \pm 0.6$ & $2.4 \pm 0.1$ & $2.7 \pm 0.5$ \\
\hline $22: 6 n-3$ & $20.6 \pm 0.4^{\mathrm{ab}}$ & $23.0 \pm 0.8^{\mathrm{a}}$ & $25.8 \pm 2.0^{\mathrm{a}}$ & $17.3 \pm 1.9^{b}$ & $17.6 \pm 0.4^{b}$ & $18.8 \pm 3.1$ ab \\
\hline Total n-3PUFA ${ }^{5}$ & $29.9 \pm 0.8$ ab & $32.7 \pm 0.2^{a}$ & $33.6 \pm 3.0^{\mathrm{a}}$ & $25.9 \pm 2.9^{b}$ & $26.4 \pm 1.0^{a b}$ & $27.8 \pm 4.4^{a b}$ \\
\hline Total PUFA & $32.5 \pm 1.1$ & $34.5 \pm 0.1$ & $36.4 \pm 2.8$ & $28.5 \pm 3.1$ & $28.2 \pm 1.1$ & $30.9 \pm 4.4$ \\
\hline
\end{tabular}

Results are means $\pm \mathrm{SD}(\mathrm{n}=3)$. Values within a row with different superscript letters are significantly different $(\mathrm{P}<0.05)$.

${ }^{1}$, Totals include 15:0, 20:0 and 22:0 present in some samples at up to $0.7 \%$; $^{2}$, Predominantly n-9 isomer; ${ }^{3}$, Predominantly n-11 isomer; ${ }^{4}$, Totals include 18:3n-6, 20:2n-6, 20:3n-6, 22:4n-6 and 22:5n-6 present in some samples at up to $0.3 \%$;

5 , Totals include 18:3n-3 and 20:3n-3 present in some samples at up to $0.2 \%$; PUFA, polyunsaturated fatty acids. 
Table 6. Lipid class composition (percentage of total lipid) of

L. salmonis obtained from wild and farmed Atlantic salmon in 1995 and 2009

\begin{tabular}{|c|c|c|c|c|}
\hline \multirow[b]{2}{*}{ Lipid class } & \multicolumn{2}{|c|}{ Wild } & \multicolumn{2}{|c|}{ Farmed } \\
\hline & 1995 & 2009 & 1995 & 2009 \\
\hline $\mathrm{PC}$ & $13.9 \pm 1.5$ & $12.5 \pm 0.1$ & $13.5 \pm 2.9$ & $13.2 \pm 0.5$ \\
\hline $\mathrm{PE}$ & $14.1 \pm 2.6$ & $12.6 \pm 1.7$ & $14.2 \pm 1.8$ & $13.3 \pm 1.6$ \\
\hline $\mathrm{PS} / \mathrm{PI} / \mathrm{PA} / \mathrm{CL}$ & $5.2 \pm 3.0$ & $6.3 \pm 4.5$ & $9.9 \pm 1.9$ & $6.8 \pm 0.6$ \\
\hline Sphingomyelin & $3.7 \pm 0.8$ & $3.3 \pm 0.3$ & $3.5 \pm 1.2$ & $3.1 \pm 0.2$ \\
\hline LPC & $0.3 \pm 0.2^{a b}$ & $0.5 \pm 0.1^{\mathrm{a}}$ & $0.5 \pm 0.3^{a}$ & $0.0 \pm 0.0^{b}$ \\
\hline Total polar & $37.2 \pm 5.3$ & $35.2 \pm 3.1$ & $41.5 \pm 7.4$ & $36.5 \pm 2.0$ \\
\hline Total neutral & $62.8 \pm 5.3$ & $64.8 \pm 3.1$ & $58.5 \pm 7.4$ & $63.5 \pm 2.0$ \\
\hline Cholesterol & $10.5^{\prime} \pm 0.7^{b}$ & $8.3 \pm 0.5^{\mathrm{c}}$ & $13.3 \pm 0.8^{a}$ & $10.6 \pm 0.3$ \\
\hline Triacylglycerol & $42.2 \pm 7.5$ & $49.1 \pm 4.5$ & $34.7 \pm 8.4$ & $47.1 \pm 2.8$ \\
\hline Free fatty acid & $10.1 \pm 1.5^{\mathrm{a}}$ & $7.4 \pm 1.3^{\mathrm{ab}}$ & $10.4 \pm 1.8^{a}$ & $5.8 \pm 0.5^{b}$ \\
\hline Steryl/wax ester & Trace & Trace & Trace & Trace \\
\hline
\end{tabular}

Both wild and farmed samples were obtained from Loch Duich in 1995, and from Armadale (wild) and Machrihanish (farmed) in 2009. Results are means \pm SD ( $n=3)$.

Values within a row with different superscript letters are significantly different $(\mathrm{P}<0.05)$.

CL, cardiolipin; LPC, lyso-PC; PA, phosphatidic acid; PC, phosphatidylcholine;

PE, phosphatidylethanolamine; PI, phosphatidylinositol; PS, phosphatidylserine. 
Table 7. Fatty acid composition (percentage of total fatty acids) of $L$. salmonis obtained from wild and farmed Atlantic salmon in 1995 and 2009.

\begin{tabular}{|c|c|c|c|c|}
\hline \multirow[b]{2}{*}{ Fatty acid } & \multicolumn{2}{|c|}{ Wild } & \multicolumn{2}{|c|}{ Farmed } \\
\hline & 1995 & 2009 & 1995 & 2009 \\
\hline $14: 0$ & $2.0 \pm 0.1^{a b}$ & $2.0 \pm 0.1 \mathrm{ab}$ & $2.1 \pm 0.0^{\mathrm{a}}$ & $1.8 \pm 0.1^{\mathrm{b}}$ \\
\hline $16: 0$ & $18.7 \pm 0.7^{\mathrm{a}}$ & $18.3 \pm 1.4^{\mathrm{ab}}$ & $17.9 \pm 0.5^{\mathrm{ab}}$ & $16.2 \pm 0.3^{b}$ \\
\hline 18:0 & $3.8 \pm 0.1$ & $3.7 \pm 0.4$ & $3.9 \pm 0.5$ & $3.6 \pm 0.1$ \\
\hline Total saturated $^{1}$ & $25.1 \pm 1.1$ & $24.7 \pm 2.1$ & $25.4 \pm 0.9$ & $22.6 \pm 0.3$ \\
\hline $16: 1 n-9$ & $1.7 \pm 0.3$ & $1.8 \pm 0.1$ & $1.7 \pm 0.4$ & $1.5 \pm 0.1$ \\
\hline $16: 1 n-7$ & $2.7 \pm 0.1^{b}$ & $3.2 \pm 0.1^{\mathrm{a}}$ & $2.3 \pm 0.2^{\mathrm{c}}$ & $2.1 \pm 0.0^{\mathrm{c}}$ \\
\hline $18: 1 n-9$ & $25.0 \pm 1.2$ & $27.0 \pm 2.7$ & $22.5 \pm 2.5$ & $21.8 \pm 1.0$ \\
\hline $18: 1 n-7$ & $1.5 \pm 0.1$ & $1.7 \pm 0.1$ & $1.4 \pm 0.2$ & $1.4 \pm 0.3$ \\
\hline $20: 1^{2}$ & $2.2 \pm 0.2$ & $2.4 \pm 0.1$ & $2.8 \pm 0.5$ & $2.2 \pm 0.1$ \\
\hline $22: 1^{3}$ & $1.0 \pm 0.0^{b}$ & $0.6 \pm 0.1^{c}$ & $2.1 \pm 0.4^{\mathrm{a}}$ & $1.0 \pm 0.0^{b}$ \\
\hline 24:1n-9 & $1.1 \pm 0.1$ & $1.1 \pm 0.1$ & $2.5 \pm 1.2$ & $1.2 \pm 0.1$ \\
\hline Total monoenes & $35.3 \pm 1.2$ & $37.6 \pm 2.9$ & $35.2 \pm 3.2$ & $31.2 \pm 1.0$ \\
\hline $18: 2 n-6$ & $0.4 \pm 0.1^{c}$ & $0.3 \pm 0.0^{\mathrm{c}}$ & $1.0 \pm 0.1^{\mathrm{b}}$ & $2.2 \pm 0.1^{a}$ \\
\hline $20: 4 n-6$ & $1.2 \pm 0.3$ & $1.4 \pm 0.1$ & $1.2 \pm 0.4$ & $1.5 \pm 0.1$ \\
\hline Total n-6PUFA ${ }^{4}$ & $2.3 \pm 0.1$ & $2.0 \pm 0.2$ & $2.9 \pm 0.5$ & $4.4 \pm 0.2$ \\
\hline $18: 3 n-3$ & $0.2 \pm 0.0^{\mathrm{c}}$ & $0.2 \pm 0.0^{c}$ & $0.3 \pm 0.0^{b}$ & $0.5 \pm 0.0^{\mathrm{a}}$ \\
\hline $20: 4 n-3$ & $0.4 \pm 0.1^{b}$ & $0.4 \pm 0.1^{b}$ & $0.6 \pm 0.1^{b}$ & $1.0 \pm 0.0^{\mathrm{a}}$ \\
\hline $20: 5 n-3$ & $5.1 \pm 0.2^{a b}$ & $6.0 \pm 0.5^{a}$ & $4.3 \pm 0.8^{b}$ & $5.5 \pm 0.1 \mathrm{ab}$ \\
\hline $22: 5 n-3$ & $4.3 \pm 0.3^{\mathrm{a}}$ & $3.5 \pm 0.3^{a b}$ & $3.0 \pm 0.5^{b}$ & $3.5 \pm 0.2^{a b}$ \\
\hline $22: 6 n-3$ & $22.1 \pm 1.2^{\mathrm{ab}}$ & $20.9 \pm 2.7^{\mathrm{ab}}$ & $18.4 \pm 3.1^{\mathrm{b}}$ & $25.7 \pm 1.2^{\mathrm{a}}$ \\
\hline Total n-3PUFA ${ }^{5}$ & $32.2 \pm 1.6^{\mathrm{ab}}$ & $31.1 \pm 3.5^{\mathrm{ab}}$ & $26.9 \pm 4.5^{b}$ & $36.8 \pm 1.3^{\mathrm{a}}$ \\
\hline Total PUFA & $34.5 \pm 1.6^{\mathrm{ab}}$ & $33.1 \pm 3.8^{a b}$ & $29.7 \pm 4.5^{b}$ & $41.1 \pm 1.4^{\mathrm{a}}$ \\
\hline
\end{tabular}

Both wild and farmed samples were obtained from Loch Duich in 1995, and from Armadale (wild) and Machrihanish (farmed) in 2009. Results are means $\pm \operatorname{SD}(\mathrm{n}=3)$.

Values within a row with different superscript letters are significantly different $(\mathrm{P}<0.05)$.

${ }^{1}$, Totals include 15:0, 20:0 and 22:0 present in some samples at up to $0.7 \%$;

${ }^{2}$, Predominantly n-9 isomer; ${ }^{3}$, Predominantly n-11 isomer; ${ }^{4}$, Totals include $18: 3 n-6,20: 2 n-6$ 20:3n-6, 22:4n-6 and 22:5n-6 present in some samples at up to $0.3 \% ;{ }^{5}$, Totals include $18: 3 n-3$ and 20:3n-3 present in some samples at up to $0.3 \%$; PUFA, polyunsaturated fatty acids. 
Table 8. Lipid content (percentage of wet weight), triacylglycerol (TAG) content (percentage of total lipid), and fatty acid composition (percentage of total fatty acids) of L. salmonis and their egg strings along with the muscle of the Atlantic salmon from which they were collected.

\begin{tabular}{|c|c|c|c|}
\hline Fatty acid & Salmon muscle & Female lice & Egg strings \\
\hline Lipid content & $3.5 \pm 0.1^{\mathrm{b}}$ & $1.6 \pm 0.2^{\mathrm{c}}$ & $6.1 \pm 1.2^{\mathrm{a}}$ \\
\hline TAG & $54.4 \pm 4.4^{\mathrm{b}}$ & $47.1 \pm 2.8^{b}$ & $72.0 \pm 1.4^{\mathrm{a}}$ \\
\hline $14: 0$ & $3.2 \pm 0.5^{a}$ & $1.8 \pm 0.1^{b}$ & $1.9 \pm 0.1^{b}$ \\
\hline $16: 0$ & $11.6 \pm 0.2^{b}$ & $16.2 \pm 0.3^{a}$ & $16.4 \pm 0.4^{\mathrm{a}}$ \\
\hline 18:0 & $3.0 \pm 0.0^{\mathrm{c}}$ & $3.6 \pm 0.1^{b}$ & $3.9 \pm 0.1^{\mathrm{a}}$ \\
\hline Total saturated $^{1}$ & $18.4 \pm 0.8^{b}$ & $22.6 \pm 0.3^{a}$ & $22.7 \pm 0.4^{\mathrm{a}}$ \\
\hline $16: 1 n-9$ & $0.0 \pm 0.0^{\mathrm{c}}$ & $1.5 \pm 0.1^{\mathrm{a}}$ & $1.3 \pm 0.0^{b}$ \\
\hline $16: 1 \mathrm{n}-7$ & $3.6 \pm 0.0^{\mathrm{a}}$ & $2.1 \pm 0.0^{b}$ & $2.1 \pm 0.1^{\mathrm{b}}$ \\
\hline $18: 1 n-9$ & $16.1 \pm 0.4^{c}$ & $21.8 \pm 1.0^{b}$ & $23.6 \pm 0.4^{\mathrm{a}}$ \\
\hline $18: 1 \mathrm{n}-7$ & $2.1 \pm 0.1^{a}$ & $1.4 \pm 0.3^{b}$ & $1.6 \pm 0.1^{\mathrm{b}}$ \\
\hline $20: 1^{2}$ & $8.7 \pm 0.3^{a}$ & $2.2 \pm 0.1^{\mathrm{c}}$ & $2.9 \pm 0.0^{\mathrm{b}}$ \\
\hline $22: 1^{3}$ & $9.7 \pm 0.5^{\text {a }}$ & $1.0 \pm 0.0^{b}$ & $1.2 \pm 0.0^{\mathrm{b}}$ \\
\hline $24: 1 n-9$ & $2.0 \pm 0.9$ & $1.2 \pm 0.1$ & $0.9 \pm 0.1$ \\
\hline Total monoenes & $42.3 \pm 0.4^{a}$ & $31.2 \pm 1.0^{\mathrm{c}}$ & $33.6 \pm 0.7^{b}$ \\
\hline $18: 2 n-6$ & $5.3 \pm 0.1^{a}$ & $2.2 \pm 0.1^{b}$ & $2.2 \pm 0.1^{\mathrm{b}}$ \\
\hline $20: 4 n-6$ & $0.7 \pm 0.0^{b}$ & $1.5 \pm 0.1^{\mathrm{a}}$ & $1.7 \pm 0.1^{\mathrm{a}}$ \\
\hline Total n-6PUFA ${ }^{4}$ & $7.0 \pm 0.2^{a}$ & $4.4 \pm 0.2^{b}$ & $4.9 \pm 0.2^{b}$ \\
\hline $18: 3 n-3$ & $1.2 \pm 0.0^{\mathrm{a}}$ & $0.5 \pm 0.0^{b}$ & $0.6 \pm 0.0^{\mathrm{b}}$ \\
\hline $20: 4 n-3$ & $1.5 \pm 0.1^{\mathrm{a}}$ & $1.0 \pm 0.0^{b}$ & $1.0 \pm 0.1^{\mathrm{b}}$ \\
\hline $20: 5 n-3$ & $5.6 \pm 0.3$ ab & $5.5 \pm 0.1^{b}$ & $6.3 \pm 0.4^{\mathrm{a}}$ \\
\hline $22: 5 n-3$ & $1.3 \pm 1.5^{\mathrm{b}}$ & $3.5 \pm 0.2^{\mathrm{a}}$ & $3.0 \pm 0.1^{\mathrm{ab}}$ \\
\hline $22: 6 n-3$ & $14.4 \pm 0.7^{c}$ & $25.7 \pm 1.2^{a}$ & $21.6 \pm 0.5^{b}$ \\
\hline Total n-3PUFA 5 & $25.9 \pm 2.7^{b}$ & $36.8 \pm 1.3^{a}$ & $32.8 \pm 0.8^{a}$ \\
\hline Total PUFA & $32.9 \pm 2.9^{b}$ & $41.1 \pm 1.4^{\mathrm{a}}$ & $37.8 \pm 0.9^{a}$ \\
\hline
\end{tabular}

Samples were obtained from Machrihanish in 2009. Results are means $\pm \mathrm{SD}(\mathrm{n}=3)$. Values within a row with different superscript letters are significantly different $(\mathrm{P}<0.05) .{ }^{1}$, Totals include 15:0, 20:0 and 22:0 present in some samples at up to $0.7 \%{ }^{2}$, Predominantly n-9 isomer; ${ }^{3}$, Predominantly $n-11$ isomer; ${ }^{4}$, Totals include 18:3n-6, 20:2n-6 20:3n-6, 22:4n-6 and 22:5n-6 present in some samples at up to $0.3 \%$; ${ }^{5}$, Totals include 18:4n-3 and 20:3n-3 present in some samples at up to $0.3 \%$; PUFA, polyunsaturated fatty acids. 
442 Table 9. Fatty acid compositions (percentage of total fatty acids) of phospholipids and triacylglycerols of

L. salmonis and their egg strings along with the muscle of the Atlantic salmon from which they were collected

\begin{tabular}{|c|c|c|c|c|c|c|}
\hline & \multicolumn{3}{|c|}{ Phospholipids } & \multicolumn{3}{|c|}{ Triacylglycerols } \\
\hline & Salmon muscle & Female lice & Egg strings & Salmon muscle & Female lice & Egg strings \\
\hline $14: 0$ & $1.3 \pm 0.1$ & $2.9 \pm 0.2$ & $4.6 \pm 0.0$ & $4.4 \pm 0.0$ & $1.5 \pm 0.0$ & $1.7 \pm 0.0$ \\
\hline $16: 0$ & $19.6 \pm 0.1$ & $18.5 \pm 0.5$ & $18.2 \pm 0.4$ & $11.6 \pm 0.0$ & $17.0 \pm 1.1$ & $18.5 \pm 0.3$ \\
\hline 18:0 & $5.9 \pm 0.1$ & $3.2 \pm 0.1$ & $2.8 \pm 0.1$ & $2.8 \pm 0.0$ & $4.3 \pm 0.2$ & $4.6 \pm 0.1$ \\
\hline Total saturated $^{1}$ & $27.3 \pm 0.1$ & $25.3 \pm 0.6$ & $26.2 \pm 0.5$ & $19.4 \pm 0.1$ & $23.3 \pm 1.3$ & $25.3 \pm 0.2$ \\
\hline $16: 1 n-9$ & $0.0 \pm 0.0$ & $1.7 \pm 0.1$ & $1.7 \pm 0.0$ & $0.0 \pm 0.0$ & $1.5 \pm 0.0$ & $1.3 \pm 0.0$ \\
\hline $16: 1 n-7$ & $1.2 \pm 0.0$ & $1.9 \pm 0.0$ & $1.5 \pm 0.1$ & $4.5 \pm 0.0$ & $2.4 \pm 0.0$ & $2.3 \pm 0.1$ \\
\hline $18: \ln -9$ & $5.7 \pm 0.0$ & $16.1 \pm 0.7$ & $16.6 \pm 1.4$ & $19.9 \pm 0.0$ & $28.3 \pm 0.9$ & $27.7 \pm 0.0$ \\
\hline $18: \ln -7$ & $1.7 \pm 0.0$ & $1.3 \pm 0.4$ & $0.9 \pm 0.0$ & $2.3 \pm 0.1$ & $1.9 \pm 0.2$ & $1.8 \pm 0.2$ \\
\hline $20: 1^{2}$ & $1.4 \pm 0.0$ & $1.2 \pm 0.0$ & $1.3 \pm 0.1$ & $10.9 \pm 0.0$ & $3.2 \pm 0.0$ & $3.6 \pm 0.0$ \\
\hline $22: 1^{3}$ & $0.6 \pm 0.0$ & $0.6 \pm 0.0$ & $0.9 \pm 0.9$ & $12.3 \pm 0.2$ & $1.4 \pm 0.0$ & $1.4 \pm 0.0$ \\
\hline $24: \ln -9$ & $1.1 \pm 0.0$ & $0.9 \pm 0.1$ & $2.4 \pm 2.1$ & $1.0 \pm 0.0$ & $0.9 \pm 0.1$ & $0.7 \pm 0.0$ \\
\hline Total monoenes & $11.7 \pm 0.2$ & $23.7 \pm 0.5$ & $25.5 \pm 1.8$ & $51.0 \pm 0.1$ & $39.6 \pm 0.6$ & $39.0 \pm 0.2$ \\
\hline $18: 2 n-6$ & $1.6 \pm 0.0$ & $1.6 \pm 0.0$ & $1.1 \pm 0.0$ & $6.1 \pm 0.0$ & $2.8 \pm 0.0$ & $2.4 \pm 0.1$ \\
\hline $20: 3 n-6$ & $0.9 \pm 0.3$ & $0.2 \pm 0.0$ & $0.3 \pm 0.1$ & $0.2 \pm 0.0$ & $0.3 \pm 0.0$ & $0.3 \pm 0.0$ \\
\hline $20: 4 n-6$ & $1.7 \pm 0.0$ & $1.0 \pm 0.1$ & $0.6 \pm 0.0$ & $0.5 \pm 0.0$ & $1.8 \pm 0.2$ & $2.0 \pm 0.0$ \\
\hline Total n-6 PUFA & $5.1 \pm 0.4$ & $3.4 \pm 0.2$ & $2.8 \pm 0.6$ & $7.9 \pm 0.0$ & $5.6 \pm 0.3$ & $5.4 \pm 0.1$ \\
\hline $18: 3 n-3$ & $0.6 \pm 0.0$ & $0.5 \pm 0.0$ & $0.5 \pm 0.0$ & $1.3 \pm 0.0$ & $0.7 \pm 0.0$ & $0.6 \pm 0.0$ \\
\hline $18: 4 n-3$ & $0.3 \pm 0.0$ & $0.2 \pm 0.0$ & $0.1 \pm 0.0$ & $1.9 \pm 0.0$ & $0.4 \pm 0.0$ & $0.3 \pm 0.0$ \\
\hline $20: 4 n-3$ & $1.0 \pm 0.0$ & $0.7 \pm 0.0$ & $0.6 \pm 0.0$ & $1.5 \pm 0.0$ & $1.2 \pm 0.0$ & $1.1 \pm 0.0$ \\
\hline $20: 5 n-3$ & $11.1 \pm 0.0$ & $4.8 \pm 0.0$ & $4.1 \pm 0.1$ & $4.4 \pm 0.0$ & $6.1 \pm 0.3$ & $6.5 \pm 0.2$ \\
\hline $22: 5 n-3$ & $2.0 \pm 0.0$ & $4.1 \pm 0.0$ & $3.6 \pm 0.2$ & $2.3 \pm 0.0$ & $3.3 \pm 0.3$ & $2.8 \pm 0.0$ \\
\hline $22: 6 n-3$ & $40.1 \pm 0.3$ & $36.8 \pm 0.9$ & $36.1 \pm 2.0$ & $9.6 \pm 0.0$ & $18.7 \pm 1.1$ & $18.2 \pm 0.5$ \\
\hline Total n-3 PUFA & $55.3 \pm 0.3$ & $47.1 \pm 0.9$ & $45.0 \pm 1.9$ & $21.2 \pm 0.0$ & $30.6 \pm 1.7$ & $29.7 \pm 0.2$ \\
\hline Total PUFA $^{6}$ & $61.0 \pm 0.1$ & $51.0 \pm 1.1$ & $48.3 \pm 1.2$ & $29.7 \pm 0.0$ & $37.1 \pm 1.9$ & $35.7 \pm 0.1$ \\
\hline
\end{tabular}

Samples were obtained from Machrihanish in 2009. Results are means $\pm \operatorname{SD}(n=3)$. Values within a row with different superscript letters are significantly different $(\mathrm{P}<0.05)$. ', Totals include 15:0, 20:0 and 22:0 present in some samples at up to $0.4 \% ;{ }^{2}$, Predominantly n-9 isomer; ${ }^{3}$, Predominantly n-11 isomer; ${ }^{4}$, Totals include $18: 3 n-6,20: 2 n-6,22: 4 n-6$ and 22:5n-6 present in some samples at up to $0.5 \%{ }^{5}$, Totals include $20: 3 n-3$ present in some samples at up to $0.2 \%$;

${ }^{6}$, Includes C16 PUFA; PUFA, polyunsaturated fatty acids. 
Table 10. Lipid class composition (percentage of total lipid) of Lepeophtheirus spp. from Atlantic salmon, sea trout and halibut

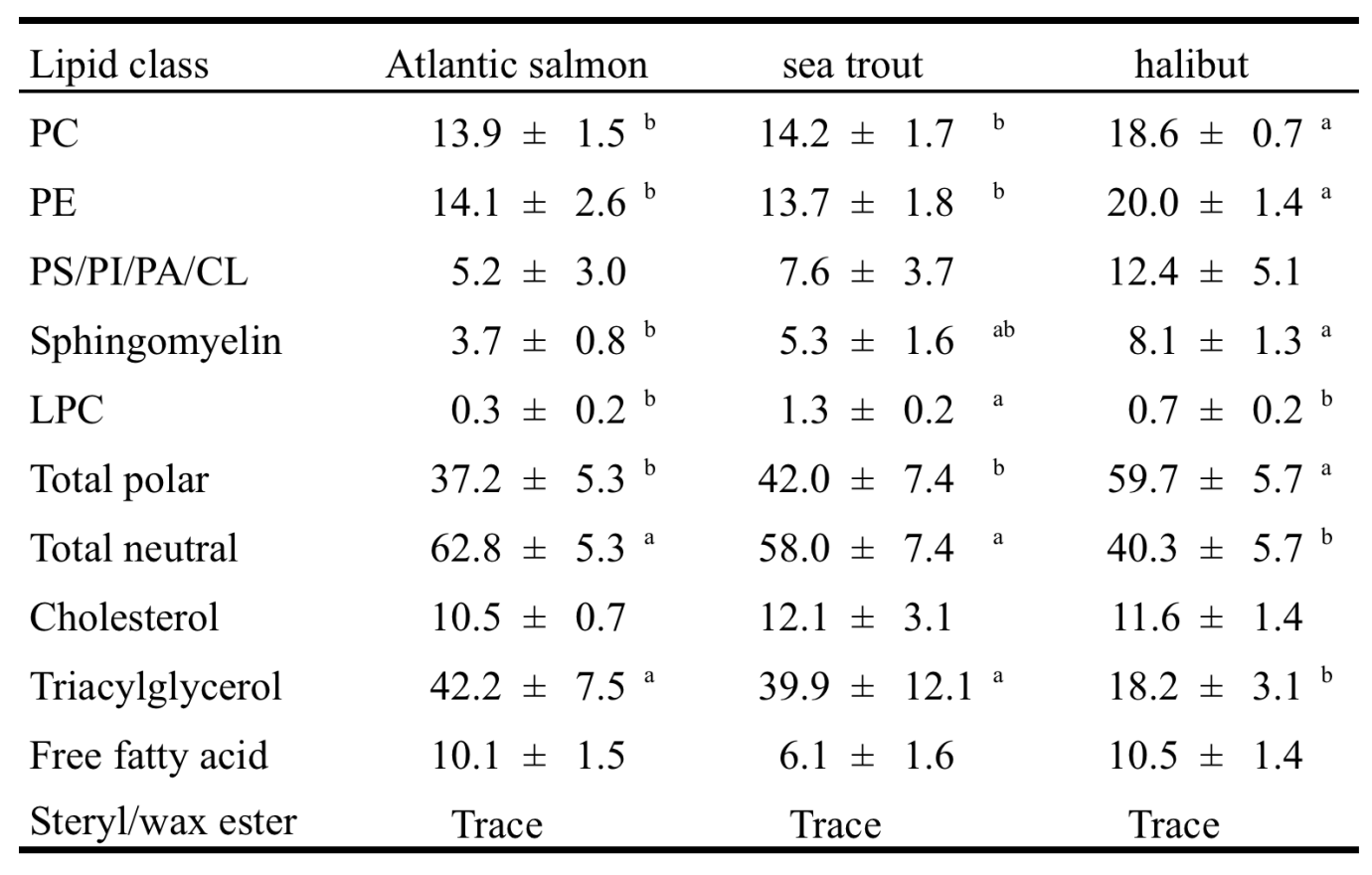

Results are means $\pm \mathrm{SD}(\mathrm{n}=3)$. Values within a row with different superscript letter are significantly different $(\mathrm{P}<0.05)$. CL, cardiolipin; LPC, lyso-PC; PA, phosphatidic acid; PC, phosphatidylcholine; PE, phosphatidylethanolamine; PI, phosphatidylinositol; PS, phosphatidylserine. 
Table 11. Fatty acid composition (percentage total fatty acids) of Lepeophtheirus spp. from Atlantic salmon, sea trout and halibut.

\begin{tabular}{|c|c|c|c|}
\hline Fatty acid & Atlantic salmon & sea trout & halibut \\
\hline $14: 0$ & $2.0 \pm 0.1^{\mathrm{a}}$ & $1.0 \pm 0.3^{b}$ & $0.5 \pm 0.2^{b}$ \\
\hline $16: 0$ & $18.7 \pm 0.7^{\mathrm{a}}$ & $17.4 \pm 1.0^{\mathrm{ab}}$ & $15.0 \pm 2.0^{b}$ \\
\hline $18: 0$ & $3.8 \pm 0.1^{\mathrm{b}}$ & $4.9 \pm 0.7^{a b}$ & $5.1 \pm 0.4^{\mathrm{a}}$ \\
\hline Total saturated $^{1}$ & $25.1 \pm 1.1$ & $24.9 \pm 1.0$ & $21.6 \pm 3.2$ \\
\hline $16: 1 n-9$ & $1.7 \pm 0.3$ & $1.6 \pm 0.1$ & $1.4 \pm 0.1$ \\
\hline $16: \ln -7$ & $2.7 \pm 0.1^{\mathrm{a}}$ & $2.4 \pm 0.2^{\mathrm{a}}$ & $0.9 \pm 0.2^{b}$ \\
\hline $18: \ln -9$ & $25.0 \pm 1.2^{\mathrm{a}}$ & $18.8 \pm 4.3^{b}$ & $8.8 \pm 0.4^{\mathrm{c}}$ \\
\hline $18: \ln -7$ & $1.5 \pm 0.1^{b}$ & $1.8 \pm 0.1^{\mathrm{a}}$ & $0.8 \pm 0.1^{c}$ \\
\hline $20: 1^{2}$ & $2.2 \pm 0.2^{a}$ & $1.9 \pm 0.1^{\mathrm{a}}$ & $1.4 \pm 0.2^{b}$ \\
\hline $22: 1^{3}$ & $1.0 \pm 0.0$ & $0.8 \pm 0.3$ & $0.5 \pm 0.2$ \\
\hline $24: 1 n-9$ & $1.1 \pm 0.1$ & $2.3 \pm 1.1$ & $3.6 \pm 1.7$ \\
\hline Total monoenes & $35.3 \pm 1.2^{\mathrm{a}}$ & $29.7 \pm 2.8^{b}$ & $17.6 \pm 2.1^{\mathrm{c}}$ \\
\hline $18: 2 n-6$ & $0.4 \pm 0.1$ & $0.8 \pm 0.4$ & $0.9 \pm 0.2$ \\
\hline $20: 4 n-6$ & $1.2 \pm 0.3$ & $1.1 \pm 0.1$ & $0.9 \pm 0.1$ \\
\hline Total n-6PUFA ${ }^{4}$ & $2.3 \pm 0.1^{b}$ & $3.3 \pm 0.4^{\mathrm{a}}$ & $3.8 \pm 0.4^{a}$ \\
\hline $18: 3 n-3$ & $0.2 \pm 0.0$ & $0.3 \pm 0.0$ & $0.2 \pm 0.1$ \\
\hline $20: 4 n-3$ & $0.4 \pm 0.1^{\mathrm{a}}$ & $0.5 \pm 0.0^{\mathrm{a}}$ & $0.3 \pm 0.0^{b}$ \\
\hline $20: 5 n-3$ & $5.1 \pm 0.2^{a}$ & $5.7 \pm 0.1^{\mathrm{a}}$ & $4.2 \pm 0.4^{b}$ \\
\hline $22: 5 n-3$ & $4.3 \pm 0.3^{\mathrm{a}}$ & $2.5 \pm 0.2^{b}$ & $1.4 \pm 0.4^{\mathrm{c}}$ \\
\hline $22: 6 n-3$ & $22.1 \pm 1.2^{b}$ & $22.2 \pm 2.1^{b}$ & $35.8 \pm 4.9^{a}$ \\
\hline Total n-3PUFA ${ }^{5}$ & $32.2 \pm 1.6^{b}$ & $31.5 \pm 2.1^{\mathrm{b}}$ & $42.1 \pm 5.6^{\mathrm{a}}$ \\
\hline Total PUFA & $34.5 \pm 1.6^{b}$ & $34.8 \pm 2.4^{b}$ & $45.9 \pm 5.5^{\mathrm{a}}$ \\
\hline
\end{tabular}

Results are means $\pm S D(n=3)$. Values within a row with a different superscript letter are significantly different $(\mathrm{P}<0.05)$. ${ }^{1}$, Totals include 15:0, 20:0 and 22:0 present in some samples at up to $0.7 \%{ }^{2}$, Predominantly $n-9$ isomer; ${ }^{3}$, Predominantly n-11 isomer; ${ }^{4}$, Totals include 18:3n-6, 20:2n-6, 20:3n-6, 22:4n-6 and $22: 5 n-6$ present in some samples at up to $0.3 \%{ }^{5}$, Totals include $18: 3 n-3$ and $20: 3 n-3$ present in some samples at up to $0.2 \%$; PUFA, polyunsaturated fatty acids. 